\title{
Trade Union Responses to Labour Immigrants: Selective Solidarity
}

\author{
ROLLE ALHO, Faculty of Social Sciences, University of Turku, Finland
}

\begin{abstract}
The Finnish service sector trade union Palvelualojen ammattilitto or Service Union United has the largest amount of migrant members of all Finnish trade unions. It walks the narrow line between defending the perceived interests of its members from the 'threat' of labour immigration, and simultaneously trying to act as an immigrantfriendly force. This qualitative case study analyses the outcomes of the union's strategies in questions related to immigration. The outcomes affect different immigrant groups in a different manner. Furthermore, the established quasi-state character of the Finnish trade union movement affects both the strengths and weaknesses of its strategies. The politicized anti-immigration views in the Finnish society indirectly to some degree impact trade union strategies. Results suggest that the lay distinction between 'us' and 'them' based on nationality still shapes trade union strategy in a way that can be labeled selective solidarity.
\end{abstract}

Key words: immigration, trade union strategy, immigration policy, inclusion, exclusion, migrants

\section{Introduction}

Labour immigration is a contested topic in many European countries. On one hand, it is seen as one of the solutions to the challenges welfare states face regarding ageing populations. Both at the nation-state level and in the business world, ethnic diversity is often positively associated with economic growth and the spread of new, valuable ideas (e.g. Florida 2002; Trux 2010). Pro-migrant NGOs stress that the right to migrate is a fundamental human right. On the other hand, the financial crisis since 2008 has negatively affected labour markets (Bartsch and Scirankova 2012). In these uncertain times, vast sections of the native populations perceive labour immigration as a critical issue. Perceptions regarding immigration - whether positive or negative - are shaped by personal experiences in neighbourhoods and labour markets, but also indirectly by the strategies of different institutional actors.

This article looks at the types of outcomes trade union strategies have around questions related to the immigration process. The term "strategy" refers to trade unions' goal-oriented and relatively well-established ways of operating. The term "immigration process" is 
understood broadly as both the processes related to entry into Finland and the integration of immigrants already living in the country.

Trade union responses to migration have gained increased societal importance following the European Union enlargements of 2004 and 2007 (Krings 2009; Marino $2012,6)$. The enlargement processes have increased internal EU mobility, which has implications for trade unions in the receiving countries (Alsos and Odegaard 2007; Krings 2009). Previous research has shown that trade unions can be influential actors in shaping national immigration policy (Menz 2011). They also influence immigrants' position in the receiving society by facilitating or hindering their inclusion (Penninx and Roosblad 2000; Milkman 2010; Marino 2012; Ristikari 2013).

The trade union under scrutiny in this article is the Service Union United (in Finnish, Palvelualojen ammattiliitto, later also referred to as SUU or the union). This union was selected because, with its 230,000 members, it is the largest Finnish trade union in terms of membership, and in absolute terms it has the largest migrant membership of all Finnish trade unions (around 9,000). Furthermore, the service sector is one of the key sectors as regards the employment of immigrants (Könönen 2012). The union defines as migrants those members who in the union membership form have not declared as their first language one of the national languages (Finnish, Swedish, or Sami).

This article critically elaborates the outcomes of two central SUU strategies during the period 2000-2011, as identified in earlier research. Firstly, the SUU actively opposes the liberalization of immigration policy (Alho 2012). Secondly, the SUU has opted for a universalistic strategy toward its migrant members, with no organizational changes regarding the union's structure in combination with emphasizing cultural and linguistic aspects of immigration (Alho 2008, 2012). The article builds on these insights by reflecting on the types of outcomes the aforementioned SUU strategies have. Additionally, I include newer research material from 2011-2013. The outcomes are assessed with regard to wider labour market impacts, their effects concerning the union's members, and the position of migrant workers. The article also assesses the relationship between the strengthened politicised anti-immigration sentiments in Finnish society and trade union strategy.

Trade union strategies are not formed in isolation: in addition to trade unions, employer organizations are influential actors regarding immigration and their choices affect the outlook of trade unions (Menz 2011). Therefore, their views are contrasted with those of the SUU. In addition, the article contrasts the arguments of the Finnish Free Movement activist network with SUU's, as the network has publicly criticized the immigration policies that the union strives for. Furthermore, the Finnish political parties' views on immigration are contrasted with the SUU's, since the parties have a bearing on the strategic choices of the SUU (and vice versa). 
The main focus of the article is the assessment of trade union strategy outcomes. The research question is, what types of outcomes do the strategies of the SUU regarding immigration and immigrants have? The outcomes are assessed in relation to the national labour markets, the position of the union itself, and the position of the migrant. In addition, the article assesses the credibility of the arguments by which the SUU explains its strategies.

In the research literature, the immigration question is perceived as difficult for trade unions, as immigration entails an increase in the workforce in receiving labour markets, which native workers might perceive as a threat to their position (Caviedes 2010; Guerin-Gonzales 1993; Kühne 2013, 60-78; Marino 2012; Penninx and Roosblad 2000; Roosblad 2002). Scholarly debates on trade union strategies in relation to immigration have varied between pessimistic accounts that emphasize working class divisions and racism that impede solidarity toward migrants (see e.g. Virdee 2000) and interpretations that point to how trade unions increasingly assess the inclusion of migrants as a power resource (Milkman 2010; Haus 2002; Watts 2002; Bengtsson 2013). In short, trade unions' response regarding migration has varied between inclusion and exclusion on the basis of national versus international solidarity. The idea or goal of "global working class solidarity" expressed by many actors in the early days of trade unionism and the labour movement (see e.g. Briggs 2001) is a notion that trade unions have never been able to effectively implement. Despite Marx' insistence on workers having no country, trade union practice has seldom been able to move beyond the frame of national identity and national interests (Hyman 2001, 39).

Globalization, European integration, and the transnationalization of labour markets notwithstanding, the national institutional context in which trade unions operate affects their strategic choices on questions regarding migration (Penninx and Roosblad 2000; Krings 2009; Marino 2012; Alho 2013). Therefore this article begins with a brief introduction to the Finnish institutional context in terms of labour markets, followed by a description of the migration setting. The second section outlines the research design. This is followed by a presentation of the empirical findings. The last section concludes by summarizing and analyzing the key findings.

\section{The Finnish labour market context}

This section describes the labour market setting within which the Service Union United operates, as this context has been shown to enable and constrain trade union strategy (Marino 2012; Penninx and Roosblad 2000; Wrench 2004). Understanding the relationship between actor and structure is essential in order to make sense of societal action. Consequently, trade union strategy is not deterministically influenced by "external" forces such as globalization or the transnationalization of the labour markets. 
The Finnish labour market system can be classified as corporatist and striving for consensus in a centralized collective bargaining system. In short, corporatism entails that interest groups such as trade unions are coordinated into the institutionalized decision-making system (see e.g. Lijphart 1999, 171-184). Trade unions in such contexts are characterized by a close relation to official state actors and to state policy. In Finland, this has been visible, for example, in the fact that the trade union movement has been able to influence even the state's foreign policy, a domain that is usually not considered a traditional trade union issue (see Bergholm 2003). Finnish trade unions also gain influence by having links to (mainly) left-wing political parties (ibid.). An indication of the close links is that two of the presidents of the SUU belong to The Social Democratic Party of Finland and one to The Left Alliance. In the Finnish presidential elections in 2012 the union financially supported the candidates of these parties in addition to the candidate of The Greens of Finland (information publicly available on the web pages of the Finnish National Audit Office). The aforementioned close links to the state and politically established parties are important trade union power resources (e.g. Korpi 1978). These links also enable trade unions to shape the political agenda on questions regarding migration (e.g. Krings 2009; Penninx and Roosblad 2000, 14). Paradoxically, a trade union's strong and established institutional position can include a weakness in terms of a lack of progressive strategies (e.g. cooperation with social movements) that might improve the situation of migrants (ibid.,196).

The Service Union United is a merger trade union established in 2000. It belongs to the Central Organization of Finnish Trade Unions - SAK (later SAK), which is the umbrella organization of Finnish "blue collar" trade unions. It represents trade unions in industry, transport, private services, and the culture and journalism sectors. Approximately three quarters of the SUU's members and the majority of its employees are female. The SUU represents and negotiates on behalf of wage earners who are mainly employed in the low wage areas of the private service sector. The majority of its members work in retail, restaurant work, and cleaning.

\section{The Finnish migration context}

Immigration to Finland has increased rapidly since the beginning of the 1990s and the topic has recently become highly politicized (e.g. Haavisto 2011; Jutila and Sundell 2012; Saukkonen 2013). For instance the success of the Euro-critical and populist The Finns Party has largely been explained by its anti-immigration stance. This is not to say that the rise of the The Finns Party should solely be explained by its stance toward immigration; the party's success is strongly related to deep-lying disappointments with the established parties (see e.g. Jutila and Sundell 2012). Nevertheless, several Finns Party MP's have spoken against certain immigrant groups' right to be in the country, and implied links between immigration, crime, and abuse of the welfare system. Despite these voices, consecutive Finnish governments have accepted that the 
country has become a country of immigration. This is observable in the Government programs of the 2000 s, which emphasized the economic gains of labour immigration and integration of migrants into society. It is also noteworthy that despite the politicization of anti-immigrant stances, nationally comparative research indicates that attitudes expressed toward immigration have on average, in a European perspective, been rather positive in Finland (see Ervasti et al. 2008).

Language and integration programs for immigrants have been financed by the state since the 1990s (e.g. Forsander 2002). Immigrant associations and other NGOs also play a significant role as channels of integration (Pyykkönen 2007; Saksela-Bergholm 2009). Traditionally reasons for immigration to Finland have been based on marriage or "humanitarian” reasons (Säävälä 2013). Studying has also been an important motivation for migrating to Finland since a relatively long time. Recently work-related migration to Finland has increased (Ritari 2013). The percentage of foreign-born population living in the country is a little over 5\% (Statistics Finland 2013). However, this figure does not take into account short-term labour immigration, which has increased (von Hertzen-Oosi et al. 2009; Alho 2011; Helander, Alho and Saksela-Bergholm 2011). The largest groups of foreign nationals are, in descending order, Estonians, Russians, Swedes, Somalis, Chinese, Thai, Iraqi, Turks, and Indians (Statistics Finland 2013). The labour market disadvantage of immigrants has been documented (e.g. Ahmad 2005; Alho 2008, 2010; Forsander 2002; Könönen 2012; Wahlbeck 2005; Wrede and Nordberg 2010). Foreign nationals' unemployment rate is approximately three times higher than that of natives, although there are large variations by nationality (Statistics Finland 2013).

The citizenship of the immigrant affects his/her position: EU, European Economic Area, Swiss, and Liechtenstein's citizens do not need work permits in order to work in Finland, in contrast to migrants who are not citizens of these countries, the so called third country nationals. However, restrictions on entry into different labour market sectors vary. Third country nationals' access to work permits for "white collar" jobs is not assessed by government officials in terms of the "need of labour," whereas this is the case as regards "working class" occupations, which the Service Union United (and SAK) represents. In the weakest labour market position are migrants who have no legal right to reside in the country (sans-papier or undocumented migrants). According to the Free Movement activist network, which (in addition to the NGO Finnish Refugee Council) supports the undocumented, the amount of undocumented people in Finland is "probably a few thousand" (email response 14.8.2013). 


\section{European approaches to trade unions, migration and migrants}

The way in which trade unions react to migration and migrants indicates something about their identity and frame of solidarity. Their strategies in these questions have varied significantly across countries and unions. Rinus Penninx and Judith Roosblad (2000) have argued on the basis of experiences gathered from seven West European countries from 1960 to 1993 that the institutional position of trade unions in the national labour market context affects their strategic repertoire towards immigration and immigrants. Penninx and Roosblad distinguish between a position from below and $a$ position from above in the outlook of trade unions. The former refers to trade unions in a weak institutional position with little means to influence state policies, whereas the latter refers to unions that have strong opportunities to influence state policies. Finnish unions no doubt belong to the latter category.

Unions that have a strong institutional link to the state (position from above) tend to support and follow the policies advocated by the state, whereas unions in a weaker institutional position (position from below) are in a more independent position and therefore able to challenge state policies in terms of migration and migrants (Penninx and Roosblad 2000). Marino (2012) has in a similar vein showed that in relation to xenophobic parties' electoral success in Italy and the Netherlands in 2000-2008, Italian trade unions, which are not as structurally embedded as the Dutch unions are, actually strengthened their commitment to migrants' rights, whereas the Dutch unions' emphasis on these issues decreased. The Italian unions were more able than their Dutch counterparts to confront the worsening political climate towards immigrants. This was because Italian unions are less institutionally embedded than the Dutch unions and rely more on immigrant inclusion. Italian unions' stronger ideology based on "universal solidarity" and "equality of all workers" also played a role (ibid.).

According to John Wrench's (2004) comparative study on trade union responses to immigrants and ethnic minorities in the United Kingdom and Denmark in 1999-2002, the differences found were due to the antagonistic British labour market context versus the more consensual Danish labour market setting. According to Wrench,

"By the 1990s there was in the UK far greater and more established range of policies and structures than in Denmark, with self-organization structures for black and ethnic minority members within unions and positive action measures such as special training for minorities who are under-represented in union positions, and reserved seats on executive bodies. ... In Denmark, the unions held on much longer to an 'equal treatment' view. In terms of special policies the Danish unions embraced changes in union structures to a much lesser degree. Instead the emphasis has been more on improving ethnic minorities' participation in unions without significant change to current structures" (Wrench 2004, 7).

Earlier research (Alho 2008) showed that the strategies of the Service Union United resemble the Danish universalistic model. 


\section{Research design}

This qualitative case study covers the period from the establishment of the Service Union United in 2000 to 2013. Several types of empirical research material have been combined. The main material consists of 18 semi-structured and recorded qualitative face-to-face interviews with full-time officials of the SUU. The interviewees were given the opportunity to assess how immigration affects their trade union and what it implies for Finnish society. They were also asked to reflect on the position of migrants in the labour market and the kinds of strategy the SUU has implemented on questions regarding migration and migrants.

The interviews were analyzed with the method of qualitative content analysis, with the attempt to identify core themes and meanings presented by the interviewees (see e.g. Flick 2002). Some of the interviewees were contacted by email afterwards with additional specifying questions that the interviews raised. Research material was also gathered at seminars and conferences where SUU's representatives presented their views on issues regarding immigration and immigrants. Combination of various kinds of data and methods increases the results' credibility in a qualitative study and gives the researcher deeper insights to the studied phenomenon in comparison to being dependent on one single method or data (ibid.). Following the case-study logic (e.g. Flyvbjerg 2004) and taking into account the need to triangulate data, several types of data were collected parallel with the analysis during the time period 2005-2013, which facilitates an assessment of the development of SUU strategies.

In addition to the interviews, public statements of the SUU were analyzed. Examples include: the Strategy paper of the SUU for 2011-2015; the Immigration policy strategy paper of the SUU for 2009-2015, and information available on the union's website. A report on migrant members' experiences (Ritari 2013) forms part of the research material, as does a study based on a questionnaire sent to the SUU members in 2010. This article also looks at the statements of the Central Organization of Finnish Trade Unions - SAK, because SUU's and SAK's strategies are often intertwined, and the SUU is one of the trade unions that shapes the SAK's strategies.

The aforementioned material was contrasted with statements regarding immigration made by the Confederation of Finnish Industries (EK), which is the largest and most influential employer organization in Finland. A representative of EK was interviewed for this study. In addition, the views of the Finnish Free Movement activist network on immigration policy have been contrasted with the SUU's. These arguments were gathered from discussions and email exchange with two activists representing the network, and public statements made by the network. As immigration is currently a politically sensitive topic, the interviewees were guaranteed anonymity.

The interview quotes and other citations included here have been chosen to represent the most common and typical themes in the research material. They have been translated 
from Finnish by the author. In order to gain insights and to help to put the Finnish trade union context in an international context, the author participated in an international conference on the challenges of labour migration organized by the European Trade Union Institute ETUI in Belgium in 2007. The main insight from this conference was that transnational labour mobility is an important issue for trade unions Europe-wide.

Previous research (Mulinari and Neergaard 2004) has underlined the importance of distinguishing between rhetorical and concrete forms of action in terms of trade union strategy. Likewise, Czaika and Haas (2013, 41-42) point out that stated migration policies do not automatically lead to their implementation. For instance, public declarations of politicians of their intention to drastically curtail immigration are not necessarily matched by actual policies, and immigration continues at high rates (ibid.). This article builds on these insights. Accordingly, it is important to study - in addition to public statements - the concrete legislative proposals the SUU has advocated or resisted, and the actual organizational changes (if any) that it has implemented in its own union structure. It is also essential to assess the concrete outcomes that these different forms of action have for the migrant workers and society at large.

\section{Results: What are the strategies and what outcomes do they imply?}

Previous research has indicated that SUU lobbies against employer and political demands for loosening up restrictions on third country nationals entering the Finnish labour market. The demands are backed up by references to unemployment levels and to the "exploitation" of migrant workers in Finland (Alho 2012). The following interview quote sheds light on how the union, as an institutionally strongly embedded actor, lobbies for its goals regarding immigration (and other issues):

"We [the SUU] can influence [issues related to immigration] in addition to taking part in discussions in the public sphere also via the public administration; we are very active toward different bodies, ministries, and the [Finnish] government. We also cooperate with NGOs."

The union's [and SAK's] close contacts to the Social Democratic party, and to a lesser extent the Left Alliance, are also of importance as channels of influence. Concerning immigration this is visible in the fact that the Social Democratic Party's official stance is against loosening up restrictions for labour immigration from third countries, which is in accordance with the SUU's and SAK's policy. (However, some eminent Social Democrats such as Pilvi Torsti (2010) have spoken in favour of more liberal labour immigration policies.) It is important to note that a reference to the EU is absent as a channel of influencing immigration questions in the interview answers of the SUU officials, which was also true for the research material in general. The continued importance of the national level is highlighted by the fact that all Finnish trade unions combined have 
only one permanent representative in Brussels. Previous research has also indicated that migration policy in practice remains a nation-state issue (Koopmans and Statham 2005, 43; Menz 2011: 257-268). Likewise, the Finnish Construction Trade Union, another union for which immigration is an important issue, directs its strategies related to immigration foremost to the national level and not the EU-level (see Alho 2012).

The unemployment rate in Finland was around 9\% in April 2013 according to Statistics Finland. Between 6 and 7\% of the SUU's members were registered as unemployed in August 2013 (e-mail response from the SUU 10.9.2013). Furthermore, the interviewees indicated that some members are under-employed, i.e. work fewer hours than they would prefer. The union argues that increased labour immigration would have a negative effect on the Finnish labour markets that already suffer from unemployment. In this section, these SUU demands are critically scrutinized and contrasted with those of other actors involved in shaping immigration policy and/or debate such as the Confederation of Finnish Industries EK and the activist Free Movement network.

The Service Union United's strategies on immigrant inclusion have been in accordance with the model applied by the Danish trade unions (Alho 2008). No changes in union structure have been made in terms of immigrant inclusion. There are no strategies that could be labeled as positive discrimination in terms of ameliorating migrants' underrepresented position within the union structure. The union's approach to these questions is universalistic. These two central approaches, i.e. resisting the liberalization of labour immigration and a belief in an universalistic union organizational structure, have not changed based on research material gathered in 2011-2013. The union's universalistic policies have not altered the migrants' marginal position as regards influence inside the union's structure during the 13 years of its existence. One may ask why there are no special union structures for migrants, as there is a long history of special branches for other historically underprivileged groups, such as women and young people, in Finnish trade unions (see Ala-Kapee et al. 1979). The Finnish Construction Trade Union-which has opted for a Russian/Estonian-speaking branch for its immigrant members - has proportionally more activist migrant members than the SUU, which might be related to the lowering of language barriers achieved by this kind of targeted arrangement (see Alho 2012). As many as 53\% of the SUU's migrant members expressed that they have faced "quite big" or "very big" problems regarding language skills in working life (Ritari 2013: 19). One can ask whether it is plausible to expect that a member with weak native language skills would engage in trade union activity, when we know that being credibly able to articulate one's standpoints is the core of trade union activism (e.g. Lipset 1955).

From the SUU's standpoint the "ideal immigrant" is someone who works legally in the country and who is, or becomes, a member of the SUU (and vice-versa). However, the research material does not imply that the ideal immigrant would necessarily be someone who is active inside the SUU organization: it suffices to be a passive member. 
This stance is related to the modus operandi of Finnish trade unions, which operate in a corporatist labour market setting and rely on a large passive membership represented by full-time salaried trade union officials (see Kevätsalo 2005).

In a questionnaire sent to SUU members in 2010, $6 \%$ considered themselves "trade union activists" (Ahtiainen 2011: 37). Nevertheless, only $0.4 \%$ of SUU's migrant members held "positions of trust" as union activists in 2011 (Alho 2012).

Migrant members are not only under-represented as trade union members and activists, but also totally absent in leading positions in the SUU's organization. The situation is similar in other Finnish trade unions (see Ristikari 2013). One plausible explanation for the underrepresentation is that the majority (around 60\%) of the migrant members have lived in Finland for less than seven years (see Ritari 2013: 6). There might be a time lag of immigrant integration because Finland is a young immigration country.

It is also clear that the vast majority of migrant members come from countries with very different traditions and outlooks regarding trade unions in comparison with Finland (e.g. Russia, Estonia, Thailand, Somalia, and Turkey). In some countries, trade unions are not genuine democratic interest organizations, or getting involved in them involves risks. Previous research (Alho 2008) has indicated that there is a lack of knowledge about the role of trade unions in Finland among immigrants, and also in some cases fear of a negative employer reaction to joining a trade union. Nevertheless, we should not dismiss the role of discrimination and even racism as an explanation for migrant under-representation. Alho (2012) and Ristikari (2013) have found evidence of racism and ethnic prejudice among trade union representatives at the workplace level. This finding was confirmed in an interview made with a representative of the SUU in 2013. It is obvious that these phenomena also have a negative impact on immigrant inclusion. The official stance of the Service Union United speaks in favor of migrants' labour rights and anti-racism and even implies increased cultural diversity related to immigration to be a positive factor. However, these attitudes are not necessarily transmitted to the workplace level.

The SUU has approximately 9,000 members who have registered a language other than Finnish or Swedish as their first language in the SUU's membership form (July 2013), which is $3.9 \%$ of its total membership of 229,000 . The most common foreign languages among the membership were, in descending order, Estonian, Russian, English, Thai, Chinese, Arabic, and Turkish. It is evident that migrants (also non-nationals) are welcomed as members of the union. This is visible in the multilingual approach that the union has partially adopted in its official communications, i.e. on its webpages. The union has also translated some collective agreements into foreign languages and shared information in "multicultural" contexts such as the World Village Festival and at the International Cultural Centre Caisa in the capital of Finland. One of the union's branches in Helsinki has recently started providing Finnish lessons to a small group of migrant members. Immigration and immigrants are on the union's agenda. This is also 
visible in the publishing of an Immigration Strategy for 2009-2015. Furthermore, a General strategy paper for 2011-2015 identifies societal challenges to which the union must react. Immigration and immigrants are mentioned in three different contexts in the paper. The Strategy paper propagates a cautious immigration policy:

"Due to the aging of the population and economic growth in big cities some sectors of working life face a lack of workforce. This problem should however, not primarily be solved by increasing the use of workforce from outside the EU/European Economic Area. Instead the [geographical] mobility of workforce in the Finnish labour market has to be facilitated by improving housing policy and social policy"

The program also claims that a "multicultural society" increases the need for language and social skills, and that special attention should be directed to the recognition of the work-related skills of workers with a migrant background.

A central aspect in the SUU' immigration policy programs the stance against ethnic discrimination and racism, and a demand for the state to improve strategies that facilitate the integration of immigrants into Finnish society. It stresses that collective agreements also apply to migrants working in Finland. Despite increased efforts, we should not over-estimate the union's visibility to migrants: in the questionnaire sent to the SUU's migrant members (Ritari 2013), only 1.4\% indicated that they had joined the union because it had been visible in the media, and $1.8 \%$ of the respondents had become members because they had received an advertisement letter from the union. Only $5.1 \%$ of the members had joined because a union representative had recommended membership. The vast majority (62.9\%) had joined because a friend, family member, or a colleague belonging to the SUU had recommended them do so; in other words not as an outcome of the union's strategy. The most common reason expressed for joining the union was the right to income-related unemployment benefit in case of unemployment, access to legal services, and advice on work-related issues. In this sense the immigrant members do not differ from the native members (Ritari 2013). Furthermore, the effects of increased emphasis on language questions should not be over-estimated either: the SUU (and other blue collar trade unions) still face difficulties in servicing their members in non-native languages including English (Alho 2008; Kyntäjä 2011).

The interviewed SUU representatives expressed quite a positive stance on immigration and immigrants in general. Some of the interviewees indicated that dealing with "immigrant issues" implied a possibility to enrich encounters and enhance ones' cultural competence:

"[As a consequence of dealing with immigrant members] my cultural understanding has increased ... It has somehow increased my tolerance, and that is good. Although it has been challenging. It can be said that I have taken this as a process of personal growth. If I'm honest, I think we can all improve in these matters." (Interview with an SUU official) 
Another official said:

"I think [immigration] is on a general level a good thing that brings with it cultural diversity."

These two quotes express an attitude that is also present in the other interviews and, for instance, in the official printed magazine that the union distributes to its members, raising interesting questions. How to explain this positive stance toward immigration and immigrants? Support for multiculturalism and tolerance have become rather widely accepted norms in many societies (e.g. Mähönen and Jasinskaja-Lahti 2013). Nowadays no organization that wants to be taken seriously in Finland wishes to appear outright "anti-immigrant", not to mention racist (with the exception of some political activists). There might be a bias for the interviewees and union activists in general to portray themselves as tolerant, international, and open-minded. Nevertheless, the interviewees were promised anonymity, which should at least by default reduce the incentive for this kind of bias.

The expressed positive stance of the SUU can also be related to gender issues. The SUU is a largely female trade union, with women constituting the vast majority of its staff and almost $80 \%$ of its members. It has been shown that women express more positive attitudes toward immigrants than men (Jaakkola 2009).

\section{Immigration as a solution to "lack of labour"?}

In addition to the Free Movement network, the Confederation of Finnish Industries (EK) has lobbied for the liberalization of immigration policies from third countries. In contrast to the Free Movement network, its arguments have been economic rather than humanitarian. EK claims that immigration policy needs to be liberalized because of "lack of labour" and "excessive" bureaucracy related to work permits. The main dividing line between the SUU (and SAK) and the employers' organization in terms of immigration policy is their view on the existence of a lack of labour. The SUU questions the employers' strong claims regarding lack of labour. It insists that when vacancies are not filled, this is due to poor wages and other working conditions. On the basis of the research material the strategy of the employers is to highlight the "lack of labour", whereas the SUU and SAK downplay these claims. They also offer different solutions to it in contrast to the employers. The opposing explanations are apparent in the following two quotes, which highlight the different interests of employer organizations and trade unions concerning the perceived amount of labour force, and how this question is critically related to the contemporary immigration question:

"The phenomenon [of unfilled vacancies] is among other things explained by the lack of proper labour market skills and competence, social problems such as subsistence abuse and the poor motivation of Finnish workers." (EK immigration expert Riitta Wärn, Helsingin Sanomat newspaper10.3.2013) 
This same view regarding the reason for unfilled vacancies, in addition with a claim of "too generous" unemployment benefits, was manifest in the interview made with an EK official for this article. In contrast, according to the SAK's expert on immigration issues:

"Employers want to recruit foreign workforce to sectors, in which they claim there is lack of labour. The difficulty of recruiting Finnish workers to these branches depends on the fact that wages are insufficient for living, and because working conditions are bad and work contracts part-time." (SAK immigration expert Eve Kyntäjä, Helsingin Sanomat 10.3.2013)

An interviewed SUU representative in a leading position argued 2013 in a similar vein that:

"It is in the policy of the National Coalition Party [a Finnish right-wing party] and EK [the largest Finnish employer organization] to argue that by increasing the labour force [i.e. by immigration] all problems in Finland will be solved. And that is one way to deteriorate working conditions. Our [SUU's] basic task is to defend working conditions that is why we are against it [loosening up restrictions for labour immigration]".

In accordance with the statement by SAK, many SUU interviewees stressed that intensified competition and a need to minimize labour costs has increased the pace of work and had a negative impact on working conditions in the service sector. It is not the aim of this article to analyze to what extent there is an actual lack of labour in Finland. Suffice to say that employer organizations and trade unions have different interests in the question, which they publicly relate to the immigration question.

\section{The "invisible" migrants}

According to the interviews made with SUU representatives in 2013, the question of undocumented immigrants has been discussed "on some occasions" among union officials. The union has not made any public statements regarding those migrants who work "illegally" in Finland, although it has recently joined an EU-financed international project, "Fine Tune", which assesses the situation of the undocumented. The interviewees also mentioned some preliminary talks within the union to organize "some kind of an information point" for undocumented migrants, in cooperation with other trade unions. The union has together with the SAK, with a couple of thousands euros, helped to finance a medical clinic for undocumented migrants (e-mail response from an SAK official 1.10.2013). The interviewees claimed that undocumented migrants have not contacted the union. The question regarding the undocumented is by and large outside the SUU's (and other Finnish trade unions') reach. This underlines their weakness in acting outside the established industrial relations framework in concrete support of the most vulnerable and "invisible" workers in society. 
The Free Movement-network provides various kinds of support to migrants with or without legal permission to reside in Finland and lobbies for the rights of the undocumented. According to the network, the restrictive immigration policies supported by the SUU/SAK toward third country nationals exhibited by Finland (and many other countries) actually push migrant workers into exposed situations and the underground economy. This is because in some sectors of working life, work permits are issued on the basis of "lack of labour". In this assessment, made by government officials, a job-seeker registered in the Finnish (and EU/EEA) labour market should be given preference to a job-seeker from a third country. In addition, residence permits are in some cases dependent on having a job and a certain income. In contrast to the Free Movement network's viewpoint, the SUU claims that this legislation is needed because it manages immigration so that employers cannot practice "social dumping" through the use of migrant workers. The SUU (and SAK) argue that these restrictions protect the migrant worker because they give government officials the means to check that working conditions are in order. According to the Free Movement network, these measures actually weaken a migrant's bargaining power in relation to their employer. The following section assesses the validity of these arguments.

Concerning undocumented migrants, the SUU is a rather conservative actor, and has not taken concrete action in favour of this vulnerable group, which trade unions have done in some countries where they have more of a social movement character (see Caviedes 2010: 27; Haus 2002; Menz 2011, 264; Watts 2002). Nevertheless, direct comparisons cannot be made, since we have to bear in mind that in Finland undocumented migrants are quite a recent phenomenon and their amount is small in an international comparison. Labour immigration is a widely debated topic, but the position of the undocumented has not been widely politicized so far, which may at least partly explain the lack of action among Finnish unions.

A large share of the undocumented works in the cleaning sector (Könönen 2012). The so-called ethnic restaurant sector is also by and large outside trade union presence in Finland. The SUU has no strategies to organize this sector, which it sees as difficult to access (Alho 2008; 2012). It has not hired migrant organizers in order to get access into the ethnic economy, as have, for instance, some US trade unions (see e.g. Milkman 2010). Typically for the SUU, instead of directly seeking access to the ethnic economy, by for instance hiring migrant recruiters, the ethnic economy's working conditions are discussed in various working groups with other institutionalized actors:

"To my knowledge we have not actively dealt with this question [ethnic economy]. It's more like we have been involved in several working groups with employers discussing these immigration questions. We discuss what kind of programs there should be and what the state should do." (emphasis added) 
The previous interview quote is from 2005. In the interviews made in 2011 and 2013, the interviewees assessed that the problems regarding working conditions in the ethnic economy still persist. From this perspective dealing with the question in an institutional state-directed manner has not provided a solution. The union does not challenge state restrictions on third country nationals entering Finland. Quite the opposite: the SUU, together with SAK, actively (and successfully) lobbied against proposals of the 2007-2011 government to legislatively facilitate labour immigration from third countries (Alho 2012; Sund 2010).

It is obvious that these restrictions regarding work permits that are dependent on the assessment of demand of labour work to the disadvantage of the third country nationals as they imply economic costs and bureaucracy. They also generally make the existence of the individual migrant more precarious, because residence permits are in many cases linked to having a work permit (see Könönen 2012). Uncertainty around getting access to work/residence permits has also been shown to cause psychological stress for applicants (Könönen 2012; Silfver 2010). One interviewed SUU official claimed to be aware of these undesired outcomes, but defended the restrictions because "there is no real lack of workforce in Finland" (interview in 2013).

Despite the opening up of the national labour markets the SUU's lobbying strategies and claims are targeted at the national level. According to the research material, possibilities of influencing EU-level decision-making remain marginal and is limited to co-operation and information sharing with Nordic and other international trade union confederations. This is visible both in the research interviews and for instance in the 33 page SUU's official Strategy paper 2011-2015, in which goals and claims are directed only at the nation-state level. No demands or goals are made in the broader European or global context. The question of supra-national strategy is complicated due to the fact that the interests and cultures of trade unions in different national contexts are often very different (see Lehtonen 2008). It is not surprising that the SUU's claims and strategies are directed at the nation-state level, as previous research has shown that the nation-states remain the most important targets of non-state actors' claims making in the immigration field (Koopmans and Statham 2005, 43).

\section{Credibility of the exploitation and unemployment arguments for restricting immigration}

\section{The exploitation argument}

The argument put forward by the SUU and SAK that current labour immigration restrictions limit the possibility of the exploitation of migrant workers is questionable. Working conditions can be protected without geographical restrictions on the mobility of workers, for instance through increased controls at workplace level (e.g. Krings 2009). A government officials' assessment (in Finnish saatavuusharkinta) regarding 
the demand of labour is conducted for some "working class" occupations concerning the right of a third country national to work. It includes, in addition to assessing the "lack of labour", an assessment regarding the employers' capability to offer working conditions that follow legal requirements. This assessment could certainly be made when issuing work permits without making an evaluation about the "lack of labour", which undermines the argument regarding the assessment's protective capacity.

Furthermore, Finland is, on a global scale, a wealthy country. Its labour markets are despite the specific problems migrants face-much less exploitative than many working life sectors in poorer countries. From this perspective it is not credible that restrictions on entry to Finland would be in the prospective third country immigrant's interest, as the SUU and SAK claim. With the risk of stating the obvious: keeping a third country immigrant outside the Finnish labour market surely protects her/him from being exploited in the Finnish labour market. Nevertheless, barriers on entry to Finnish labour markets prevent her/him from exiting home country labour markets, which globally compared are in many cases characterized by much worse working conditions than those in Finland.

Paananen (1999) has argued that the Finnish Construction Trade Union labeled foreign workers exploited in order to be able to defend continued restrictions on labour immigration. They simultaneously gave a humanitarian impression while working against the influx of foreign work force. On the basis of my research material, it is not possible to make a similarly strong claim regarding the motivations of the SUU and SAK as to why they define migrants as exploited. There have also been severe cases in Finland of breaches of the labour rights of migrants working in the service and construction sectors (Alho 2008, 2010). Studies based on migrants' experiences confirm that migrants are more vulnerable to mistreatment in these sectors compared to natives (Alho 2008, 2010; Könönen 2012). Trade union officials are fully aware of this phenomenon (Helander, Alho and Saksela-Bergholm 2011). Furthermore, state labour inspectors confirm that immigrants more often than natives face labour law breaches (Alho 2008).

In other words, framing migrants as exploited cannot be dismissed as solely a trade union strategy aimed at defending continued restrictions of entry to Finland. Nevertheless, the exploitation-framing contributes to the SUU' and SAK's interests as they perceive it, as it gives an altruistic and humanitarian tone to the continued restrictions.

\section{The unemployment argument}

It is also questionable to defend - in SUU's terms - the aforementioned restrictions on labour immigration with the argument that they protect the Finnish workforce. The Finnish economist Sarvimäki (2013) has presented a theoretical model according to which the effect of immigration on natives' labour market position is currently likely to be low. However, Kouvonen (2012) assessed that the high proportion of immigrants in the Helsinki area has "probably to some degree" slowed down wage development in the service and construction sectors. 
We know that many immigrant groups are on average more active than natives in establishing enterprises (Joronen 2012). We could hypothesize that increased immigration would actually expand the service sector and create more work opportunities - not diminish them, as the union argues. Nevertheless, as the public statement of the SUU above indicates, the union argues for increased mobility within the national borders, rather than labour immigration, to fill labour shortages.

No doubt unemployment is a serious societal problem in Finland. Nevertheless, demographic challenges with the ageing of the population put strains on Finnish welfare states' finances. The economist Juhana Vartiainen, Director General of the Government Institute for Economic Research (VATT) in Finland, argues that one of the most serious problems regarding the Finnish national economy is the lack of supply of workforce (Yle News 6.6.2013). Vartiainen supports increased immigration and argues that municipalities actively using migrants as a resource will be successful. He stresses that unemployment and immigration are not related, as the amount of work is not fixed; therefore immigration does not work against the natives' interests.

Restrictions on labour immigration have also met criticism inside the trade union movement. The Finnish Confederation of Professionals (STTK's) chief economist, Ralf Sund, has argued that due to the benefits of internationalization and the demographic challenges "(it is in Finland's national interests to strive for an immigration policy that is as liberal as possible)" (Sund 2010).

If these economists' arguments hold true, lobbying against increased immigration is a strategy that works against the interests of SUU members and the entire Finnish society (with the premise that economic growth is desirable). However, we cannot either dismiss the idea that the current restrictions on labour immigration would in some cases protect the labour market interests of the workforce in Finland (including migrants living in Finland) in the short term. As mentioned above, immigration from abroad to the capital area has probably to some degree slowed wage increases in the service and construction sector (Kouvonen 2012). The "lack of labour" assessment for third country nationals was lifted in the Uusimaa-region (the capital area) regarding cleaning jobs at the end of 2012, despite resistance from the SUU and SAK. The interviewed SUU representatives said in 2013 that it was still too early to assess what labour market outcomes this liberalization has had.

\section{The rise of "pro" and "anti"-immigration politics and their impact on trade union strategy}

Trade unions are political actors that pay attention to the societal climate. Attitudes toward immigration and immigrants were changing in an immigration-friendlier direction in Finland until 2007 (Haavisto 2011). However, the recent rise of the anti-immigrant 
Finns Party (up from 4\% in the 2007 parliamentary elections to $19 \%$ in 2011 ) is a factor to which other political actors pay attention. It is reasonable to claim that these political currents have to some degree modified the other political parties' stances toward a more cautious direction as regards immigration. For instance, the right-wing government of 2007-2011 did not enforce its plans for liberalizing labour immigration from third countries, even though it held a majority in parliament. The rising unemployment since the year 2008, and the opposition of the left wing parties, The Finns Party, and blue collar trade unions including the SUU, no doubt affected this outcome.

It is easier for voluntary activist groups such as the Free Movement network to challenge state immigration policies than for a large and well-established trade union such as the SUU to do so. The latter is dependent on the acceptance of a large share of the native working population. For instance, the Finns Party's success is strongest among those parts of the working class that the SUU and SAK represent.

However, trade unions also shape, and not only reflect, perceptions regarding labour immigration in the public sphere Therefore it is probable that the SUU's rather negative framing regarding liberalizing labour immigration not only reflects a popular critical stance toward the phenomenon, but also strengthens it, as institutional actors shape the opinions of ordinary citizens. Nevertheless, the SUU does not interpret or present immigration as a cultural threat, a phenomenon that has been visible among various actors in many parts of Europe in the 2000s (e.g. Citrin and Sides 2008; Koopmans et al. 2005).

Many commentators have argued that Finnish society is for the time being divided into "two camps", positive and negative, regarding immigration, immigrants, and multiculturalism (e.g. Jasinskaja and Mähönen 2013). Interestingly, we can identify both of these approaches in the research material concerning the SUU. The union's stance is characterized by ambivalence. The union to some degree assesses the organization of migrants already living in Finland as a power resource. It has applied some concrete measures in order to obtain tangible outcomes in this regard. These aspects have most likely contributed to migrants increasingly joining the union. Furthermore, they symbolically imply that migrants are welcomed as members. The migrant membership has increased from around 1,000 in the year 2002 to approximately 9,000 in 2013. The SUU assesses the number of migrants working in the sectors it represents as being around 40,000 (interview in 2013). This means that trade union density among migrants is far lower than among the whole population in the sectors the SUU represents, which is around $50 \%$ on the basis of the interviews.

The analysis of the research material indicates that it is not possible to give one single straightforward answer to the "classical question" as to whether the trade union under scrutiny is for or against immigrants. The answer depends on the category of immigrants referred to. The SUU's strategies imply different outcomes for different groups of immigrants. 


\section{Discussion}

The SUU's resistance to liberalization of labour immigration is understandable in the current Finnish political climate, characterized by high unemployment and the rise of a populist and anti-immigration political alternative offered by the Finns Party. The union's position reflects a protectionist stance, which places the Finnish workforce's (perceived) interests above those of the prospective immigrants from third countries. This is probably quite a successful strategy toward the part of the population that perceives immigration as a threat, as it gives the impression that the union protects the natives. Nevertheless, this strategy can be criticized for cynicism or Realpolitik, as the labour market implications of immigration are assessed to be minor (see Sarvimäki 2013). It must also be pointed out that labour recruitment from abroad is already fully possible owing to free movement within the EU (in addition to the EEA, Nordic countries not belonging to the EU, Switzerland, and Liechtenstein). With the exception of the construction sector (see Alho 2013) labour import has been modest, even though Finland has been a member of the EU for nearly two decades. Furthermore, Finland imposed no transition periods for the entry of Rumanian and Bulgarian citizens into the Finnish labour market, when these countries joined the EU in 2007. Immigration from these low-wage countries to Finland has been minimal. Neither has the recent massive unemployment in Southern Europe led to significant labour migration to Finland, even though citizens of these countries are free to enter the Finnish labour market. These facts speak against the fears of large-scale labour market impacts of liberalizing labour immigration, which the SUU, together with the SAK, have actively raised to public discussion.

To the part of the population that does not perceive immigration as a threat, the strategy of associating immigration with negative labour market effects in the manner of SUU/SAK (and parts of the party political left that they are linked with) may give a impression of trade unions as defenders of a narrow, short-term self-interest. Nevertheless, it has to be pointed out that restrictions on labour immigration are not in an international comparison exceptionally strict in Finland.

Portraying immigration as a labour market threat can also have negative outcomes for how natives perceive immigrants living in the country. On the other hand, it is likely that the restrictive stance toward increased immigration has some support among the immigrant population. There are international examples of immigrants resisting immigration, because they perceive it as a threat to their societal position (Briggs 2001). Nevertheless, there are also studies that point to immigrants favouring liberal immigration policies (e.g. Rouse, Wilkinson and Garand 2010). This kind of research is lacking in Finland, but we may assume immigrants' perceptions in this question to vary just like within the population as a whole.

The position of the union does not portray "global working class solidarity", as it makes a distinction between "us" and "them" on the basis of nationality. The nation- 
state is the cognitive and actual frame of reference for the union. The SUU acts like a union in a "position from above", to use the term of Penninx and Roosblad. It does not challenge the status quo regarding state immigration policy, or the populist discourse that interprets labour immigration as a threat, in a way that for instance the less institutionally embedded Italian trade unions have done.

The SUU's strategies reflect the ambivalence existing in Finnish society regarding immigration. Despite its rather negative outlook regarding further labour immigration, the union has publicly spoken against racism and discrimination. It has made some efforts to serve its members in an increasing multilingual manner. It has also emphasized that the state should improve its integration policies directed at immigrants. Despite being symbolically important, these are expressions of solidarity that cost little and require no structural changes that would increase migrants' participation inside the union. The union has not challenged - but actually defended - work/residence permit requirements, which in many cases entail insecurity and costs to migrants. The union's emphasis on relating immigration with culture and language issues has not altered ethnic power inequalities inside the union organization. According to Mulinari and Neergaard (2004), the culturalization discourse regarding immigrants in the Swedish trade union movement hides the structural inequalities in the trade union movement and at the state level. Concerning the Finnish context, the powerful positions in the SUU are, as in other Finnish trade unions, held by native Finns, whereas migrants are with a few exceptions passive members.

Positions of authority in trade unions provide income and/or a varying degree of societal, in some cases political, influence for their holders. Furthermore, trade unions are hierarchical organizations, in which those in positions of power often use different means to preserve and increase their power (e.g. Kevätsalo 1986; Michels 1911). From this standpoint it is reasonable to question whether the holders of these positions would actively engage in measures that concretely enhance the newcomers' (in this case migrants) position inside their organization. Processes of power redistribution may meet considerable resistance in trade unions (Penninx and Roosblad 2000, 11-12). In other words, there are obvious incentives for social closure (for social closure see Weber 1922/1978) in order to monopolize the aforementioned resources within the trade unions. Consequently migrants' own motivation is crucial, as power is seldom given away.

Finland is a young immigration country and most of the migrant members of the SUU have lived in the country for less than seven years (Ritari 2013). Reaching a position of authority in a large trade union usually requires years, in some cases decades, of activity in the trade union movement. The coming years will show whether the trade unions will act as a veritable channel of influence for the migrant population, something that, by and large, they are not at present. Migrant associations have played a more significant role in this respect (Pyykkönen 2007; Saksela-Bergholm 2009). 
The union's strategies imply close links to the state. There are interesting parallels between the SUU's/SAK's stance toward the Finnish state's immigration policy, and the Finnish trade union's position toward official Finnish foreign policy. According to Bergholm (2008), the Finnish trade union movement has only with rare exceptions questioned or challenged state foreign policy. This is still the case today. For instance, top trade union leaders take part in official state visits to economically important countries. This relates to the quasi-state character of the Finnish trade union movement and is visible in the weakness of unions in defending the most vulnerable migrant workers such as the undocumented, or those working in the ethnic restaurant sector, which is virtually without a trade union presence. The solidarity of the union reaches those migrants who are relatively well integrated in the Finnish labour market. However, the strong link to the state has led to ample opportunities for trade unions to reach their goals in terms of working conditions. Their strong power resources have, for instance, contributed to the by international terms relatively high wages in the service sector. These wages also apply to immigrants, including non-unionized migrants (except for the undocumented who rarely can make any claims toward their employer). In this regard, the majority of migrants working in the occupations that the SUU represents benefit from the union.

Prospective immigration from third countries renders the question of international solidarity a more critical issue than was the case in previous decades. Finnish trade unions have historically interpreted international solidarity as a sort of "development aid", which means supporting weak trade unions in the third world or other poor countries. International solidarity is now, however, because of intensified globalization, a more critical "on your doorstep" question in terms of labour immigration.

It is useful to contrast immigration to Finland with internal mobility in the country. Immigration to Finland is minor compared to the mobility of people inside the country. In fact, in 2012 internal migration between Finnish municipalities was around nine times higher than immigration to Finland (Statistics Finland 2013). The Service Union United does not frame this kind of geographical mobility as a problem even if it by default leads to the same kind of "competition for jobs" as mobility from outside the Finnish state borders. For an employed/unemployed person in the Finnish labour market, an internal native immigrant moving to their location represents in principle the same kind of "threat" as an immigrant from abroad. One could even argue that internal immigration (which the union advocates instead of immigration to fill labour shortages) forms a more serious form of labour market competition from the perspective of the individual SUU member, as the immigrant often lacks the kind of socio-economic capital that is appreciated in the Finnish labour market (Forsander 2002). In sum, the lay distinction between "us" and "them" based on nationality still shapes trade union strategy in a way that can be labeled as selective solidarity. 


\section{References}

Ahmad, Akhlaq. 2005. Getting a job in Finland: The social networks of immigrants from the Indian subcontinent in the Helsinki metropolitan labour market. $\mathrm{PhD}$ thesis, University of Helsinki.

Ahtiainen, Lasse. 2011. Järjestötutkimus 2010. Helsinki: Palvelualojen ammattiliitto PAM ry.

Ala-Kapee, Pirjo, Marja Valkonen and Pirjo Österberg. 1979. Nainen SAK:laisessa ammattiyhdistyksessä. Katsaus naisten ansioiden kehitykseen sekä naisten järjestäytymiseen ja toimintaan. Helsinki: Suomen Ammattiliittojen Keskusjärjestö SAK r.y.

Alho, Rolle. 2008 Maahanmuuttajat suomalaisessa ay-liikkeessä: tapaus PAM. In: Going Global. Ay-liikkeen menestysresepti globaalissa ajassa?, edited by Mika Helander, pp. 283-329, Helsinki: Minerva kustannus Oy.

---. 2010. Maahanmuuttajien kokemukset ja ammattiliittojen näkemykset työehtojen polkemisesta. In Vieraita työssä: työelämän etnistyvä eriarvoisuus, edited by Sirpa Wrede and Camilla Nordberg, pp. 93-121 Helsinki: Gaudeamus.

---. 2011. Virolaiset pääkaupunkiseudun työmarkkinoilla. In Totta toinen puoli? Työperäisen maahanmuuton todelliset ja kuvitellut kipupisteet, edited by Mika Helander, pp. 119-22, Helsinki: SSKH Skrifter 31.

---. 2012. Rakennusliiton ja Palvelualojen ammattiliiton maahanmuutto- ja maahanmuuttajastrategiat. Työelämän tutkimus.10(1): 38-54.

---. 2013. Trade union responses to transnational labour mobility in the Finnish-Estonian context. Nordic Journal of Working Life Studies. 3(3): 133-53.

Alsos, Kristin and Anne Mette Odegaard. 2007. De sikrer Norges framtid pa mindestelonn. Osteuropeisk arbeidskraft pa petroleumsanlegg pa land. Fafo-rapport 32.

Bartsch, Gorja and Daniela Scirankova. 2012. Large differences in regional labour markets show asymmetric impact of the economic crisis (Statistics in focus, 2012/54), Luxemburg.

Bengtsson, Erik. 2013. Swedish trade unions and European Union migrant workers. Journal of Industrial Relations 55(2): 174-89.

Bergholm, Tapio. 2003. A short history of SAK. Helsinki: SAK.

Briggs, Vernon. M. 2001. Immigration and American unionism. Ithaca, NY: Cornell University Press.

Caviedes, Alexander. A. 2010. Prying open fortress Europe. The turn to sectoral labour migration. Lanham: Lexington Books.

Citrin, Jack and John Sides. 2008. Immigration and the imagined community in Europe and the United States. Political Studies. 56(1): 33-56.

Czaika, Mathias and Hein de Haas. 2013. The effectiveness of immigration policies. Population and Development Review 39(3): 487-508.

Ervasti, Heikki. Torben Fridberg, Mikael Hjerm, and Kristen Ringdal. 2008. Nordic social attitudes in a European perspective. Cheltenham: Edward Elgar.

European Social Survey http://www.europeansocialsurvey.org/ (accessed 4 November 2013) 
Flick, Uwe. 2002. An introduction to qualitative research. London: Sage.

Florida, Richard. 2002. The rise of the creative class. New York: Basic Books.

Flyvbjerg, Bent. 2004. Five misunderstandings about case-study research. In: Qualitative research practice, edited by C. Seale, G. Gobo, J.F. Gubrium and D. Silverman, pp. 420-34 London: Sage.

Forsander, Annika. 2002. Luottamuksen ehdot. Maahanmuuttajat 1990-luvun suomalaisilla työmarkkinoilla. PhD thesis. University of Turku.

Guerin-Gonzales, Camille and Carl Strikwerda. (eds.) .1993. The politics of immigrants workers. Labour and migration in the world economy since 1830. New York: Holmes \& Meyer.

Haavisto, Camilla. 2011. Conditionally one of 'us'. A study of print media, minorities and positioning practices. $\mathrm{PhD}$ thesis, University of Helsinki.

Hardy, Jane, Line Eldring and Thorsten Schulten. 2012 Trade union responses to migrant workers from the 'new Europe': a three sector comparison in the UK, Norway and Germany. European Journal of Industrial Relations 18(4): 347-63.

Haus, Leah. 2002. Unions immigration and internationalization. New challenges and changing coalitions in the United States and France. New York: Palgrave Macmillan.

Helander, Mika, Rolle Alho and Sanna Saksela-Bergholm. 2011. Ulkomaisten tilapäistyöntekijöiden työehdot ja sosiaaliturva tutkimuksen kohteena. In: Totta toinen puoli. Työperäisen maahanmuuton todelliset ja kuvitellut kipupisteet, edited by Mika Helander, pp. 128-152, Helsinki: SSKH Skrifter 31.

Helsingin Sanomat 10.3.2013.

Hyman, Richard. 2001. Understanding European Trade Unionism. Between Market, Class \& Society. London: Sage Publications Ltd.

Jaakkola, Magdaleena. 2009. Maahanmuuttajat suomalaisten näkökulmasta. Asennemuutokset 1987-2007. Helsinki: Helsingin kaupungin tietokeskus.

Johansson, Jesper. 2012 Swedish employers and trade unions, varieties of capitalism and labour migration policies. Nordic Journal of Migration Research 2(4): 325-34.

Joronen, Tuula. 2012. Maahanmuuttajien yrittäjyys Suomessa. PhD thesis. University of Helsinki.

Jutila, Karina and Björn Sundell. 2012. The populism of the Finns party - fun or ugly? Helsinki: Think Tank Magma.

Kevätsalo, Kimmo. 1986. Marginal labour power and the Finnish trade union movement. Acta Sociologica 29(1): 31-44.

---. 2005. Yhdestoista hetki. Uuden vuosituhannen ay-liike paikallistasolla. Helsinki: Käyttötieto Oy.

Koopmans, Ruud, Paul Statham, Marco Giugni and Florence Passy. 2005. Contested citizenship: Immigration and cultural diversity in Europe. Minneapolis and London: University of Minnesota Press.

Koopmans, Ruud and Paul Statham. 2005. Migration and ethnic relations as a field of political contention: An opportunity structure approach. In: Challenging immigration and ethnic relations politics. Comparative European perspectives, edited by Ruud Koopmans and Paul Statham, pp. 13-56, Oxford: Oxford University Press. 
Korpi, Walter. 1978. Arbetarklassen i välfärdskapitalismen: arbete, fackförening och politik i Sverige. Bokförlaget Prisma i samarbete med Institutet för social forskning. Tampere: Vastapaino.

Kouvonen, Seppo. 2012. Pääkaupunkiseudun palkat ovat toista maata.Hyvinvointikatsaus 4.

Krings, Torben. 2009. Organised labour and migration in the global age: A comparative analysis of trade union responses to migrant labour in Austria, Germany, Ireland and the UK. PhD thesis, Dublin City University.

Kühne, Peter. 2013. Deutsche Gewerkschaften und Immigrantinnen/Immigranten ohne deutschen Pass. In: DGB heute: Ordnungsfaktor, Gegenmacht, Auslaufmodell?, edited by Burkhard Jacob, pp. 60-78, Bonn: Paul-Rugenstein Verlag.

Kyntäjä, Eve. 2011. Viron- ja Venäjänkielisten maahanmuuttajien kokemukset työyhteisön ja ammattiliiton jäsenenä. In: Totta toinen puoli? Työperäisen maahanmuuton todelliset ja kuvitellut kipupisteet, edited by Mika Helander, pp. 59-84, Helsinki: SSKH Skrifter 31.

Könönen, Jukka. 2012. Prekaari työvoima ja työn uudet hierarkiat metropolissa. Sosiologia 49(3): 190-205.

Lehtonen, Riikka. 2008. Suomalaisten ammattiliittojen kansainvälinen yhteistyö. In: Going Global. Ay-liikkeen menestysresepti globaalissa ajassa, edited by Mika Helander, pp. 141-164, Helsinki: Minerva kustannus Oy.

Lijphart, Arend. 1999. Patterns of democracy. Government forms and performance in thirty-six countries. New Haven: Yale University Press.

Lipset, Seymour. 1955. Union democracy: The internal politics of the international typographical union. Glencoe, IL: The Free Press.

Marino, Stefania and Judith Roosblad. 2008. Migration and trade unions. A comparison between Dutch and Italian trade unions' actions and strategies. Transfer 14(4): 625-38.

Marino, Stefania. 2012. Trade union inclusion of migrant and ethnic minority workers: Comparing Italy and the Netherlands. European Journal of Industrial Relations 18 (1): 5-12.

Michels, Robert. (1916/1966) Political parties. A sociological study of the oligarchical tendencies of modern democracy. New York: Free Press Paperback.

Menz, Georg. 2011. The political economy of managed migration. Nonstate actors, Europeanization and the politics of designing migration policies. Oxford: Oxford University Press.

Milkman, Ruth. 2010. Introduction. In: Working for justice. The L.A. model of organizing and advocacy, edited by Ruth Milkman, Joshua Bloom, and Victor Narro, pp. 1-19, Ithaca: Cornell University Press.

Mulinari, Diana and Anders Neergaard. 2004. Den nya svenska arbetarklassen. Umeå: Boréa.

Mähönen, Tuuli Anna and Inga Jasinskaja-Lahti. 2013. Ryhmäsuhteet ja akkulturaatio. In:Muuttajat: Kansainvälinen muuttoliike ja suomalainen yhteiskunta, edited by Tuomas Martikainen, Pasi Saukkonen and Minna Säävälä, pp. 247-61, Helsinki: Gaudeamus Helsinki University Press.

Official Statistics of Finland (OSF). 2013. Preliminary population statistics [e-publication]. 
June2013, Appendix figure 3. Intermunicipal migration by quarter 1993-2012 and preliminary data 2013. Helsinki: Statistics Finland (accessed: 4.11.2013).

Paananen, Seppo. 1999. Suomalaisuuden armoilla. Ulkomaalaisten työnhakijoiden luokittelu. PhD thesis, University of Helsinki.

Penninx, Rinus and Judith Roosblad (eds.) 2000. Trade unions, immigration, and immigrants in Europe 1960-1993. New York: Berghahn Books.

Pyykkönen, Miikka. 2007. Järjestäytyvät diasporat. Etnisyys, kansalaisuus, integraatio ja hallinta maahanmuuttajien yhdistystoiminnassa. PhD thesis. University of Jyväskylä.

Ristikari, Tiina. 2013. Finnish trade unions and immigrant labour. PhD thesis, University of Tampere.

Ritari, Anni. 2013. Töissä Suomessa. Raportti Palvelualojen Ammattiliiton maahanmuuttajajäsenten kokemuksista. Helsinki: PAM.

Roosblad, Judith. 2002.Vakbonden en immigranten in Nederland (1960-1997). PhD thesis, University of Amsterdam.

Rouse, Stella. M., Betina C. Wilkinson and James C. Garand. 2010. Divided loyalties? Understanding variation in Latino attitudes toward immigration. Social Science Quarterly 91:856-882.

Saksela-Bergholm, Sanna. 2009. Immigrant associations in the metropolitan area: Forms of mobilisation, participation and representation, $\mathrm{PhD}$ thesis, University of Helsinki.

Sarvimäki, Matti. 2013. Muuttoliikkeet, työmarkkinat ja julkinen talous. In: Muuttajat. Kansainvälinen muuttoliike ja suomalainen yhteiskunta, edited by Tuomas Martikainen, Pasi Saukkonen and Minna Säävälä, pp. 203-19, Helsinki: Gaudeamus Helsinki University Press.

Saukkonen, Pasi. 2013. Maahanmuutto- ja kotouttamispolitiikka. In: Muuttajat. Kansainvälinen muuttoliike ja suomalainen yhteiskunta, edited by Tuomas Martikainen, Pasi Saukkonen and, Minna Säävälä, pp. 81-97, Helsinki: Gaudeamus Helsinki University Press.

Service Union United's Strategy paper for 2011-2015: http://www.pam.fi/fi/medialle/ Documents/Tavoiteohjelma2011 2015.pdf (accessed 4 November 2013)

Service Union United's Immigration policy strategy paper for 2009-2015: https://www. pam.fi/fi/info/strategia/Documents/PAMinmaahanmuuttopolohjelma2009-2015.pdf (accessed 4 November 2013)

Service Union United's homepage: http://www.pam.fi/fi/sivut/default.aspx (accessed 4 November 2013).

Silfver, Olga. 2010.Vääränlaiset huippuosaajat? Entisen Neuvostoliiton alueelta tulleiden asiantuntijoiden kiinnittyminen suomalaiseen työelämään. In: Vieraita työssä. Työelämän etnistyvä eriarvoisuus, edited by Sirpa Wrede and Camilla Nordberg Helsinki, pp. 122-46, Helsinki: Gaudeamus Helsinki University Press.

Sund, Ralf. 2010. Lisääntyvä maahanmuutto - Suomen kehityksen luonteva jatke. In: Meno-paluu Eurooppaan. Maahanmuutto ja siirtolaisuus - eilen tänään ja huomenna. Helsinki: Eurooppalainen Suomi ry. 
Säävälä, Minna. 2013. Maahanmuutto perheilmiönä. In: Muuttajat. Kansainvälinen muuttoliike ja suomalainen yhteiskunta, edited by Tuomas Martikainen, Pasi Saukkonen and, Minna Säävälä, pp. 101-40, Helsinki: Gaudeamus Helsinki University Press.

Torsti, Pilvi. 2010. http://www.pilvitorsti.fi/pelastusohjelma/2010/08/25/kuvitteleolevasi mamu-homo-tai-patkatyolainen/ (accessed 29 November 2013)

Trux, Marja-Liisa. 2010. No zoo: Ethnic civility and its cultural regulation among the staff of a Finnish high-tech company. PhD Thesis, Aalto University.

Virdee, Satnam. 2000. A Marxist critique of black radical theories of trade-union racism. Sociology 34(3): 545-65.

von Hertzen-Oosi, N., H. Harju, N. Haake and T. Aro. 2009. Ulkomaalaisten tilapäinen työnteko Suomessa. Työ- ja elinkeinoministeriön julkaisuja 37/09.

Wahlbeck, Östen. 2005. Turkkilaiset maahanmuuttajat yrittäjinä Suomessa. Paikallinen ja transnationaali sosiaalinen pääoma. Janus 13(1): 39-53.

Watts, Julie. R. 2002. Immigration policy and the challenge of globalization. Ithaca/ London: Cornell University Press.

Weber, Max. 1978. Economy and society. Berkeley: University of California Press.

Wrede, Sirpa and Camilla Nordberg (eds.) 2010. Vieraita työssä. Työelämän etnistyvä eriarvoisuus. Helsinki: Gaudeamus.

Wrench, John. 2004. Breakthroughs and blind spots: Trade union responses to immigrants and ethnic minorities in Denmark and the UK. Oslo: Fafo.

YLE News 6.6.2013

http://yle.fi/uutiset/vatt_chief_immigrantfriendly cities the biggest_winners/6677426 